TITLE:

\title{
Crucial role of vinexin for keratinocyte migration in vitro and epidermal wound healing in vivo.
}

\section{AUTHOR(S):}

Kioka, Noriyuki; Ito, Takuya; Yamashita, Hiroshi; Uekawa, Natsuko; Umemoto, Tsutomu; Motoyoshi, Soh; Imai, Hiroshi; ... Watanabe, Hideto; Yamada, Masayasu; Ueda, Kazumitsu

\section{CITATION:}

Kioka, Noriyuki ... [et al]. Crucial role of vinexin for keratinocyte migration in vitro and epidermal wound healing in vivo.. Experimental cell research 2010, 316(10): 1728-1738

\section{ISSUE DATE:}

2010-06-10

URL:

http://hdl.handle.net/2433/130802

\section{RIGHT:}

@ 2010 Elsevier Inc.; この論文は出版社版でありません。引用の際には 出版社版をご確認ご利用ください。; This is not the published version. Please cite only the published version. 


\title{
CRUCIAL ROLE OF VINEXIN FOR KERATINOCYTE MIGRATION IN VITRO AND EPIDERMAL WOUND HEALING
} IN VIVO

\author{
Noriyuki Kioka $^{{ }^{*}}$, Takuya Ito $^{1}$, Hiroshi Yamashita ${ }^{1}$,Natsuko Uekawa ${ }^{2}$, Tsutomu \\ Umemoto $^{1}$, Soh Motoyoshi ${ }^{1}$, Hiroshi Imai ${ }^{2}$, Kenzo Takahashi ${ }^{3}$, Hideto Watanabe ${ }^{4}$, \\ Masayasu Yamada ${ }^{2}$, and Kazumitsu Ueda ${ }^{1,5}$
}

${ }^{1}$ Division of Applied Life Sciences, ${ }^{2}$ Division of Applied Biosciences, Graduate School of Agriculture, Kyoto University, Sakyo, Kyoto 606-8502, Japan,

${ }^{3}$ Department of Dermatology, Graduate School of Medicine, Kyoto University, Sakyo, Kyoto 606-8507, Japan

${ }^{4}$ Institute for Molecular Science of Medicine, Aichi Medical University, Nagakute, Aichi 480-1195, Japan

${ }^{5}$ Institute for Integrated Cell-Material Sciences (iCeMS), Kyoto University, Sakyo, Kyoto 606-8507, Japan

\footnotetext{
*Address correspondence to Noriyuki Kioka, Ph.D., Division of Applied Life Sciences, Graduate School of Agriculture, Kyoto University, Sakyo-ku, Kyoto 606-8502, Japan E-mail: nkioka@kais.kyoto-u.ac.jp

Fax: +81-75-753-6104
} 


\begin{abstract}
In the process of tissue injury and repair, epithelial cells rapidly migrate and form epithelial sheets. Vinexin is a cytoplasmic molecule of the integrin-containing cell adhesion complex localized at focal contacts in vitro. Here, we investigated the roles of vinexin in keratinocyte migration in vitro and wound healing in vivo. Vinexin knockdown using siRNA delayed migration of both HaCaT human keratinocytes and A431 epidermoid carcinoma cells in scratch assay, but did not affect cell proliferation. Induction of cell migration by scratching the confluent monolayer culture of these cells activated both EGFR and ERK, and their inhibitors AG1478 and U0126 substantially suppressed scratch-induced keratinocyte migration. Vinexin knockdown in these cells inhibited the scratch-induced activation of EGFR, but not that of ERK, suggesting that vinexin promotes cell migration via activation of EGFR. We further generated vinexin $(-/-)$ mice and isolated their keratinocytes. They similarly showed slow migration in scratch assay. Furthermore, vinexin (-/-) mice exhibited a delay in cutaneous wound healing in both the back skin and tail without affecting the proliferation of keratinocytes. Together, these results strongly suggest a crucial role of vinexin in keratinocyte migration in vitro and cutaneous wound healing in vivo.
\end{abstract}

Keywords: keratinocytes, migration, wound healing, EGFR, vinexin 


\section{Introduction}

In the process of tissue injury and repair, epithelial cells rapidly migrate into the defective region and proliferate to reconstruct the barrier of epithelial sheets $[1,2]$. These steps involve a variety of growth factors, their receptors and downstream signaling molecules, including cytoskeletal and cell adhesion molecules [3]. Among them, epidermal growth factor (EGF), its receptor (EGFR), and extracellular-signal regulated kinase (ERK) are known to regulate the motility and proliferation of keratinocytes during wound healing [4-8]. In addition, integrin-mediated signal transductions, initiated by binding to extracellular matrix (ECM) molecules such as fibronectin and laminins, have been shown to play important roles in cutaneous wound healing [9]. For example, disruption of alternatively spliced exons of fibronectin induces abnormal skin wound healing and delays re-epithelialization [10]. An expression switch from $\alpha 6 \beta 4$ hemidesmosomal integrin to $\alpha 3 \beta 1$ integrin localized at focal contacts occurs at wound sites [11]. Loss of integrin $\beta 1$ expression or targeted disruption of the integrin $\beta 4$ signaling domain has been shown to impair cutaneous wound healing $[12,13]$. When ligands bind integrins, their intracellular domains become activated, and assemble cytoplasmic molecules such as paxillin, talin, focal adhesion kinase (FAK), and vinculin, forming a complex at a focal contact region. Although these molecules composing the cell adhesion complex are supposed to participate in cell migration, their individual roles have not been determined in keratinocytes.

Vinexin is a cytoplasmic molecule of the integrin-containing cell adhesion complex localized at focal contacts in vitro [14]. This molecule was first identified as vinculin-binding protein [14], and by homology of domains, it belongs to a small adaptor family of vinexin, CAP/ponsin, and ArgBP2 [15]. To date, several vinexin variants have been reported $[14,16,17]$ : vinexin $\alpha$ contains a SoHo domain and three SH3 domains and shows tissue-specific expression, whereas vinexin $\beta$ contains only three SH3 domains and is ubiquitously expressed [14, 18]. SH3 domains of vinexin are associated with vinculin, WAVE2, DLG5/lp-dlg, Abl, and Cbl [14, 19-21], and the SoHo domain with flotillin and estrogen receptor $[22,23]$. Through the interaction with 
vinculin, vinexin $\alpha$ stimulates the accumulation of F-actin at focal contacts [24].

Recently, we showed that vinexin $\beta$ interacts with ERK and induces its sustained activation in NIH3T3 cells $[25,26]$, and that vinexin $\beta$ both enhances and sustains the activation of EGFR in COS7 cells [27]. These results strongly suggest that vinexin not only serves as a molecule of focal adhesion complex, but also regulates EGF-mediated signal transduction in the process of cell migration.

In this study, we investigated the roles of vinexin in keratinocyte migration in vitro and wound healing in vivo. Vinexin knockdown in HaCaT human keratinocytes and A431 epidermoid carcinoma cells suppressed cell migration in vitro, and diminished the scratch-induced activation of EGFR. We further generated vinexin-null mice. Vinexin-null primary keratinocytes exhibited slow cell migration. Furthermore, vinexin-null mice showed delayed cutaneous wound healing of both the back skin and tail without affecting the proliferation of keratinocytes. These results indicate a crucial role of vinexin in cutaneous wound healing. 


\section{Materials and methods}

Cell culture-A431 human epidermoid carcinoma cells were obtained from Cell

Resource Center for Biomedical Research, Institute of Development, Aging and Cancer, Tohoku University. Both HaCaT human keratinocytes and A431 cells were maintained in DMEM containing 10\% fetal bovine serum (FBS). Primary keratinocytes were isolated from 1- to 3-day-old mice and maintained in keratinocyte basal medium KBM-2 (Lonza, Walkersville, MD) as reported [28].

RNA interference- Stealth siRNA for human vinexin (vinexin siRNA1:

GGAGGACCCAGAAAUUCGGAACGUU, vinexin siRNA2:

ACAUCUGCCUGAUCCGCAAGGUGAA), for the control

(GGACCAGACAAACUUAGGCAGGGUU), and for GFP

(CACAUGAAGCAGCACGACUUCUUCA) were synthesized by Invitrogen.

Transfection of the control or vinexin-specific siRNA $(10 \mathrm{nM})$ was performed using LipofectAmine RNAiMAX (Invitrogen) according to the manufacturer's instructions. Three days after transfection, cells were used for the in vitro scratch assay or biochemical analysis. Cell proliferation was defined as the ratio of BrdU-incorporating nuclei with total nuclei using the 5'-Bromo-2'-deoxyuridine Labeling \& Detection Kit I (Roche Diagnostics).

Immunoblot analysis-Lysates from cultured cells or tissues of mice were prepared as described previously [26, 29]. The lysates were then subjected to SDS-PAGE. Immunoblot analysis was completed as previously described [26]. Primary mouse monoclonal antibodies were as follows: EGFR (1:1000, BD Biosciences), paxillin (1:1000, BD Biosciences), FAK (1:1000, BD Biosciences), p130CAS (1:5000, BD Biosciences), and vinculin (1:5000, Sigma). Primary rabbit polyclonal antibodies (phospho-EGFR (pY845, pY992, pY1068, and pY1173) (1:1000, Cell Signaling Technology), ERK (1:4000, Santa Cruz Biotechnology), phospho-ERK (1:3000, Cell Signaling Technology), and vinexin [14]) were also used. 
Immunostaining-A431 cells were cultured to confluence on cover slips and the medium was changed to DMEM containing $0.5 \%$ FBS two hours before scratching with a $200-\mu 1$ pipette tip. Detached cells were removed and the remaining cells were incubated with DMEM containing 0.5\% FBS. Cells were fixed with $3.7 \%$ formaldehyde, and then permeabilized with $0.4 \%$ Triton-X100, and immunostained as described previously [27]. The fluorescence images were taken with a PASCAL confocal microscopy system (Carl Zeiss Co., Ltd).

Generation of homozygous vinexin (-/-) mice-Since transcriptional variants, vinexin $\alpha, \beta$, and $\gamma$, use a different first exon, it is difficult to disrupt all first exons at once. Thus, we generated a targeting vector deleting part of an intron and an exon encoding the first SH3 domain (Supplemental Fig. S1A). The first SH3 domain is shared by all known vinexin variants $[14,16,17]$ and is necessary for association with vinculin and WAVE2, and for determining the subcellular localization of vinexins $[19,24,30]$. Vinexin genomic DNA was obtained by PCR using primers located in exons. A 5' $1.2 \mathrm{~kb}$ fragment of genomic DNA was generated by digestion with SmaI and NcoI, blunted, and then ligated into the EcoRV site of pTargetB vector (kindly provided by Dr. K. Kadomatsu). [31] (Supplemental Fig. S1A). A 3' 6.5 kb fragment was generated by digestion with NcoI (blunted) and XhoI, then ligated into SalI (blunted) and XhoI sites of the vector (Supplemental Fig. S1A). The targeting vector contained MC1NeopA for positive selection and PGKDTA for negative selection. The targeting vector was linearized by XhoI digestion, and then electroporated into TT2 ES cells [32]. The G418-resistant clones obtained were screened by nested PCR and confirmed by Southern blot analysis (described below). ES cells heterozygous for the desired targeting were aggregated with 8-cell stage embryo. One clone (\#38) successfully contributed to the germ-line in mouse chimeras. Mice were backcrossed 6-8 generations to obtain the C57BL background. Animals were provided with standard rodent chow and tap water ad libitum.

To confirm the absence of vinexin protein in vinexin (-/-) mice, lysates were isolated from various tissues followed by immunoblotting using anti-vinexin antibody. Expressions of both vinexin $\alpha$ and $\beta$ in vinexin (-/-) mice were completely impaired in 
tissues examined, including the lung, heart, liver (Supplemental Fig. S1C), kidney, and skeletal muscle (data not shown). Expression levels of vinculin and paxillin, two other proteins localized at focal contacts, were not changed.

Mice with the vinexin allele $(+/+,+/-$, and -/-) were born at the predicted Mendelian ratio (67:128:72 $\mathrm{n}=267)$. Vinexin $(-/-)$ mice were born without any apparent defect and were indistinguishable from the wild-type mice, indicating that the vinexin gene is not essential for embryonic development. They grew at a similar rate to the wild type (data not shown) without apparent defects. They were also fertile and showed normal parenting. Histopathological analysis of tissues from vinexin (-/-) mice, such as heart, lung, kidney, colon, skin, testis and ovary, revealed no major defects compared to tissues from littermate controls (data not shown).

Animal experiments were conducted in accordance with the institutional policies following approval from the Animal Experimentation Committee of the Graduate School of Agriculture, Kyoto University.

Genotyping of mice-The genotypes of mutant mice were determined by nested PCR and confirmed by Southern blot analysis of genomic DNA from tail biopsies. Briefly, tail samples were incubated in lysis buffer (10 mM Tris (pH8.0), $150 \mathrm{mM} \mathrm{NaCl}, 10 \mathrm{mM}$ EDTA, $0.1 \%$ SDS and $1 \mathrm{mg} / \mathrm{ml}$ proteinase $\mathrm{K}$ ) at $55^{\circ} \mathrm{C}$ for four hours, followed by purification with phenol/chloroform and precipitation with isopropyl alcohol. The first PCR for nest PCR was performed using primers (P1

\section{AAGCTGAGCGCAGAGCTGGACAAGGACCTG, R1}

CCTGGAGTCTGCAGTTTCTAAGTCTCTCCC) under the following amplification conditions: $94^{\circ} \mathrm{C}$ for $3 \mathrm{~min}, 25$ cycles of $94^{\circ} \mathrm{C}$ for $25 \mathrm{~s}, 65^{\circ} \mathrm{C}$ for $25 \mathrm{~s}$, and $72^{\circ} \mathrm{C}$ for 150 s. A primer set (P2 TGCGAACTTTTCCGGAGGAGGTGGTGTCACTGG and R2 TCCCTACCTGTCTCTCTCACTCACCTCCAC) was used for the second PCR under the same amplification conditions to detect the wild-type allele $(1.5 \mathrm{~kb})$ and targeted allele $(2.5 \mathrm{~kb})$. In some experiments, another primer set (P2 and R3 TGGGTGGAAACATTCCAGGCCTGGGTGAGAGG) was used to detect the targeted allele only. For Southern blotting, SalI/EcoRI-digested genomic DNA was probed with a 0.4-kb fragment immediately upstream of the $5^{\prime}$ arm (Supplementary Fig. S1A, S1B). 
In vivo wound healing study-For the in vivo wound healing assay, 18-week-old female mice were anesthetized by i.p. injection with Avertin. For wound healing experiments of back skin, two full thickness wounds were generated on the shaved backs of each mouse using an 8-mm diameter sterile biopsy punch. After wounding, all mice were housed separately and wounds were air-dried. Each wound was photographed with a ruler using a digital camera every two days. The wounded areas in the images were traced and quantitated by ImageJ. Full-thickness tail wounding experiments were performed as reported previously [33]. Briefly, 2-cm-long full-thickness wounds were created using a scalpel on the dorsal aspect of the tail of each mouse. Wounded tails were harvested at day 4 or 8 after wounding. Tails were fixed in $10 \%$ buffered formalin, decalcified, dehydrated, and embedded in paraffin. Four-micrometer sections were stained with hematoxylin and eosin. Re-epithelialized regions in the image were traced and measured by ImageJ. To examine cell proliferation, sections were stained with rat anti-Ki67 antibody using Histofine® Simple Stain Mouse MAX PO (Nichirei Biosciences Inc.) and Ki-67-positive cells were counted in the wounded area (500 $\mu \mathrm{m})$.

In vitro scratch assay-Cells were cultured to confluence on 6-well plates and the medium was replaced with DMEM containing 0.5\% FBS two hours before scratching with a $200-\mu 1$ pipette tip. Detached cells were removed and the remaining cells were incubated with DMEM containing 0.5\% FBS. In some experiments, inhibitors $(3.3 \mu \mathrm{M}$ AG1478 (Calbiochem) or $3.3 \mu \mathrm{M}$ U0126 (Cell Signaling Technology) were added to the culture media. At least eight scratched areas for each sample were marked and photographed immediately or at the indicated hours, with a Nikon TE300 inverted microscope. Migration was evaluated by measuring the difference in defect width at $0 \mathrm{~h}$ and at indicated hours after scratching. For immunoblotting, cells were cultured on 12-well plates and incubated as above, and four lines were generated by scratching. Cells were lysed with modified RIPA buffer, followed by analysis by SDS-PAGE and immunoblotting.

Migration assay-Modified Boyden chamber assay was used for examining cell migration as reported [28]. Briefly, primary keratinocytes $\left(7 \times 10^{4}\right)$ isolated from 
wild-type or vinexin (-/-) mice were plated onto Transwell chambers $(5 \mu \mathrm{m}$ pore, Corning) coated with Type I collagen. KBM-2 containing 10\% FBS was added into the lower chamber. After incubation for 6 hours, cells were fixed and stained with $0.1 \%$ crystal violet. Non-migrating cells on the upper membrane were removed with a cotton swab. Cells on the bottom surface of each membrane were photographed and counted in two fields. Experiments were performed in triplicate.

Cell attachment assay-Cell attachment assays were performed using a modification of the method reported in $[28,34]$. Briefly, 96-well tissue culture plates were coated with collagen I (BD Bioscinces) and blocked with $2 \mathrm{mg} / \mathrm{ml}$ heat-denatured BSA (Sigma) for 1 h. Primary keratinocytes $\left(8 \times 10^{4}\right)$ isolated from wild-type or vinexin (-/-) mice were added to each well and cells were allowed to attach for $30 \mathrm{~min}$. After washing twice, attached cells were fixed, washed, and stained with $0.1 \%(\mathrm{w} / \mathrm{v})$ crystal violet. The stained cells was washed thoroughly and dissolved in 10\% acetic acid, and absorbance at $570 \mathrm{~nm}$ was measured.

Statistical analysis-Statistical analysis was performed using Student's paired $t$-test. 


\section{Results}

\section{Wound closure of HaCaT and A431 cells involves vinexin}

First, we examined whether inhibition of vinexin expression affects cell migration of the HaCaT human keratinocyte monolayer, using scratch assay. When siRNA for vinexin (siRNA1) was transfected into HaCaT cells, more than $90 \%$ of vinexin $\beta$ expression in HaCaT cells was suppressed under this condition (Fig. 1A). Expression of vinexin $\alpha$ was barely detectable even in control HaCaT cells (not shown). Knockdown of vinexin expression did not affect expression of any binding partners, including vinculin, ERK, and WAVE2, or other cytoskeletal and signaling molecules in these cells (data not shown). HaCaT cells transfected with control and vinexin siRNA1 were cultured up to confluence and then applied to scratch assay. Whereas cells transfected with control siRNA migrated efficiently and almost covered the defect within 24 hours after scratching (Fig. 1B, C), the vinexin knockdown cells exhibited a 50\% decrease in migration compared with control cells. A similar inhibition of cell migration was observed by transfection with another siRNA against vinexin (Supplemental Fig. S2A).

We also examined the effect on migration by vinexin knockdown in A431 epidermoid carcinoma cells, in which EGFR is overexpressed. Vinexin expression was suppressed by transfection with vinexin siRNA1 (Fig. 1D) to approximately $50 \%$. Whereas cells transfected with control siRNA migrated efficiently and almost covered the defect within 18 hours after scratching, cells with vinexin siRNA1 showed decreased migration to approximately $50 \%$ (Fig. 1E, F).

Wound closure may involve cell proliferation in addition to cell migration. To clarify the effect of vinexin knockdown on cell proliferation in this system, we performed BrdU incorporation assay on control siRNA- or vinexin siRNA1-treated cells. Vinexin knockdown did not affect the incorporation of BrdU of HaCaT cells during this experiment (Supplemental Fig. S3). Furthermore, vinexin knockdown inhibited migration of non-proliferating A431 cells treated with mitomycin C (data not shown). These results indicate that vinexin is necessary for sufficient levels of cell migration in vitro, in HaCaT keratinocytes and A431 epidermoid carcinoma cells, and that its function is independent of cell proliferation. 
Scratch-induced activation of EGFR and ERK regulates migration of HaCaT and A431 cells

Cutaneous wound healing and keratinocyte migration in vivo have been reported to involve activation of signaling molecules, including EGFR and ERK [3, 35, 36]. We previously reported that vinexin $\beta$ inhibits dephosphorylation of ERK, thereby sustaining the activation of ERK [26], or induces the anchorage-independent activation of ERK [37]. We also reported that vinexin $\beta$ induces sustained activation of EGFR in COS7 cells [27]. These results raised the possibility that vinexin regulates cell migration via EGFR-ERK-mediated signal transduction.

To test this, we first investigated whether EGFR and ERK are activated in migrating $\mathrm{HaCaT}$ or A431 cells. These cells were cultured to confluence and the monolayer cultures were scratched. Cells were then incubated, and activation of EGFR and ERK was examined by detecting their phosphorylation. As shown in Fig. 2A, phosphorylation of EGFR at 1068 tyrosine (Y1068), which is a well-known autophosphorylation site leading to the Ras/ERK pathway, increased four hours after scratching and sustained for eight hours. Total expression levels of EGFR protein did not change during this period. The phosphorylation level of ERK was also elevated by scratching, although it peaked within four hours and decreased to nearly a basal level after eight hours (Fig. 2A). Since ERK was activated prior to EGFR activation, wound-induced ERK activation is not likely to depend on wound-induced EGFR activation under our conditions. Similar activation patterns of EGFR and ERK were observed for A431 cells (Fig. 2D). These results indicate that scratching of HaCaT and A431 monolayers in vitro stimulates the activation of EGFR and ERK.

We next tested the effect of pharmacological inhibitors of these kinases. The addition of AG1478, a specific inhibitor of EGFR, or U0126, an inhibitor of ERK-activating kinase MEK, substantially impaired the coverage of the defect (Fig. 2B, C, E, F, P<0.01), suggesting that both activated EGFR and ERK are required for efficient cell migration.

Vinexin is necessary for the scratch-induced activation of EGFR but not of ERK in 


\section{HaCaT and A431 cells}

Next, using siRNA, we examined whether vinexin regulates scratch-induced activation of EGFR or ERK. In control-siRNA transfected HaCaT cells, the phosphorylation of Y1068 of EGFR significantly increased four hours after scratching, as described above. In contrast, the increase in the phosphorylation of Y1068 of EGFR was not detected in vinexin knockdown cells (Fig. 3A, C). Expression levels of EGFR were unaffected by vinexin knockdown. Interestingly, vinexin knockdown did not affect scratch-induced activation or expression of ERK. The same results were obtained by knockdown experiments using another siRNA for vinexin (Supplemental Fig. S2B).

We previously reported that vinexin sustains the phosphorylation of EGFR not only at Y1068 but also at other tyrosine residues, including autophosphorylation and src-mediated phosphorylation sites after EGF stimulation in COS7 cells [27]. Thus, we examined phosphorylation at other tyrosine residues and found that vinexin knockdown inhibited the scratch-induced phosphorylation of Y845, Y992, and Y1173 of EGFR (Fig. 3B). Knockdown of vinexin expression in A431 cells also inhibited the EGFR activated by scratching but not ERK (Fig. 3D, E). Taken together, these results suggest that vinexin facilitates migration through activation of EGFR in both $\mathrm{HaCaT}$ and A431 cells.

Vinexin is necessary for EGFR localization at the leading edge of migrating A431 cells

We previously reported that exogenous expression of vinexin delays the endocytosis of EGFR after EGF stimulation and induces the sustained phosphorylation of EGFR at the cell surface in COS7 cells [27]. Thus, we tested the effect of decreased vinexin expression on the localization of EGFR after scratching. In control cells, vinexin was colocalized with vinculin at focal contacts of the leading edge (Fig. 4A, upper panel). EGFR was localized at both the leading edge and cell-cell adhesion sites. At the leading edge, it was partially colocalized with vinexin at least (Fig. 4B). In vinexin knockdown cells, vinculin was localized at focal contacts of the leading edge as shown in control cells (Fig. 4A, bottom panel). EGFR was observed at cell-cell adhesion sites but not at the leading edge (Fig. 4B). These results suggest that vinexin is necessary for localization of EGFR at the leading edge of migrating A431 cells. 
To reveal the in vivo function of vinexin, we generated its knockout mice. Both vinexin (+/-) and (-/-) mice were viable and fertile. No abnormalities were observed under physiological conditions. Then, we isolated the primary keratinocytes from wild-type and vinexin (-/-) mice and investigated cell migration in vitro. As shown in Fig. 5A, vinexin $\beta$ was detected in wild-type primary keratinocytes but not in vinexin (-/-) keratinocytes. Vinexin $\alpha$ was scarcely detected even in wild-type keratinocytes (data not shown), suggesting that vinexin $\beta$ serves as a main variant in primary keratinocytes, similar to $\mathrm{HaCaT}$ and A431 cells. Vinexin-null keratinocytes exhibited no difference in cell morphology or cell attachment to collagen I, from wild-type keratinocytes (Fig. 5B and data not shown). However, they showed slower migration as evaluated by modified Boyden chamber assay and scratch assay (Fig. 5C, D). Phosphorylation of EGFR was not detected even in wild-type primary keratinocytes, presumably due to a small amount of phosphorylated EGFR in primary keratinocytes compared with that in immortalized cells. Together, these results suggest that vinexin is necessary for cell migration of mouse primary keratinocytes.

\section{Cutaneous wound closure on back skin and tail skin was delayed in vinexin (-/-) mice}

Next, we performed a wound-healing assay using wild-type and vinexin (-/-) mice. Two full-thickness wounds were generated on the shaved backs of each mouse using an 8-mm diameter sterile biopsy punch, and the wounded areas were measured at various time points after wounding. As shown in Fig. 6A, wound healing occurred in vinexin (-/-) mice but was delayed. Wound closure was clearly observed in control mice at day 2 after wounding, but was only slightly observed in vinexin (-/-) mice. At day 8 after wounding, more than $80 \%$ of the wound was repaired in vinexin $(+/+)$ mice, but only approximately $50 \%$ was in vinexin (-/-) mice.

Although wounding on the back skin is a useful model for examining keratinocyte migration during wound closure, it is significantly affected by contraction.

Full-thickness wounding of tail skin is a recently reported model for wound closure, where the effect of contraction is minimal [33]. Thus, we also examined the effects of vinexin gene disruption on wound closure in vivo using this model. Full-thickness wounds were generated using a scalpel on the dorsal aspect of the tail of each mouse. 
Tails were harvested at day 4 or 8 after wounding and analyzed by histology (Fig. 6B, C). At day 4, epidermal keratinocytes had started to migrate into the wounded area, and elongated epithelial projections were observed in control mice. In contrast, only limited epidermal migration was detected in vinexin (-/-) mice (Fig. 6C). Even at day 8, epithelial projections were short and re-epithelialization was substantially delayed in vinexin (-/-) mice (Fig. 6B, C). By immunostaining, three different anti-vinexin antibodies failed to detect vinexin in the wounded area. The levels of cell proliferation of keratinocytes were similar in the wounded area between control and vinexin (-/-) mice, when evaluated by immunostaining with anti-Ki-67 (Fig. 6D) antibody, suggesting that vinexin is not necessary for proliferation of keratinocytes in a wounded area. Taken together, these results indicate that vinexin facilitates wound healing in vivo, especially by acting on keratinocyte migration. 


\section{Discussion}

In this study, we have demonstrated for the first time that vinexin promotes keratinocyte migration and contributes to cutaneous wound healing. Vinexin sustains EGER activation and locates EGFR to the leading edge of migrating cells, thereby facilitating keratinocyte migration. Two different in vivo wound healing assays using vinexin (-/-) mice clearly indicated an important role of vinexin in wound healing. Our findings present vinexin as a functional member in wound healing, and provide a clue to the mechanisms of this complicated process.

The role of EGFR activation has been suggested in keratinocyte cell migration [5, 6]. We previously reported that vinexin $\beta$ sustains the EGFR activation after stimulation with EGF in COS7 cells [27]. Here we have successfully clarified how these molecules are related in cell migration. Scratching of $\mathrm{HaCaT}$ and A431 cell monolayers substantially activates EGFR, and knockdown of vinexin expression in these cells suppresses EGFR activation. Vinexin knockdown abrogated the accumulation of EGFR at the leading edge of migration, suggesting that vinexin regulates localization of EGFR. Previous studies have shown that EGFR activated by EGF ligand is rapidly internalized by c-Cbl-dependent endocytosis and degraded in lysosomes [38]. Exogenously expressed vinexin $\beta$ becomes associated with $\mathrm{c}-\mathrm{Cbl}$ and delays endocytosis, leading to the retention of EGFR at the cell surface [27], while direct interaction of vinexin with EGFR was not detected [27]. Our observations extend these previous findings and show that vinexin facilitates keratinocyte migration through EGFR activation, possibly by regulating the subcellular localization of EGFR. Although we could not examine activation of EGFR in primary keratinocytes due to low expression levels, similar inhibition patterns of cell migrations between cell lines and primary keratinocytes suggest that vinexin acts via activation of EGFR.

In contrast to EGFR, ERK activated by scratching was not affected by vinexin knockdown. We previously reported that exogenously expressed vinexin $\beta$ directly interacts with activated ERK and inhibits the dephosphorylation of ERK, leading to the anchorage-independent or sustained activation of ERK in NIH3T3 fibroblasts [25, 26]. Recently, it was reported that deletion of a variant (vinexin $\gamma$ )-specific exon fails to 
affect ERK activation in fetal female gonad, but impairs the activation in male gonad even though vinexin $\gamma$ is expressed similarly in both sexes [16]. These observations indicate that vinexin regulation of ERK activity depends on cellular machinery and that vinexin is dispensable for ERK activation induced by scratching in keratinocytes.

Here we have shown that vinexin promotes keratinocyte migration in vitro and wound healing in vivo. Intriguingly, overexpression of vinexin inhibits cell migration of v-Src-transformed NIH3T3 cells and LNCaP prostate cancer cells in vitro [39, 40]. Vinexin $\beta$ is known to be phosphorylated at leading edge by ERK $[25,39]$ and the phosphorylated and unphosphorylated form of vinexin $\beta$ is suggested to have opposite effects on migration of prostate cancer cells [39]. These findings suggest multiple roles of vinexin in cell migration. Besides the regulation of EGFR, we previously reported that vinexin interacts with cytoskeletal proteins, including vinculin and WAVE $[14,19]$. Vinculin inhibits cell migration through stabilization of focal adhesions [41, 42]. WAVE enhances lamellipodia formation leading to promoted cell migration [43]. Thus, vinexin can be predicted to have multiple roles in cell migration through its interaction with these proteins, in addition to the activation of EGFR in keratinocytes.

No major defects were found in vinexin (-/-) mice except for the delay of cutaneous wound closure, despite the ubiquitous expression of vinexin $\beta$ and tissue-specific expression of vinexin $\alpha[14,18]$. This is consistent with a previous report that deletion of a vinexin $\gamma$-specific exon had no apparent effect, except for the delay of Sox9 expression in male gonads for a limited period in embryonic development [16]. Vinexin, $\mathrm{CAP} /$ ponsin, and $\operatorname{ArgBP} 2$ contain common domain structures and form a small adaptor family. These three molecules share common binding partners, such as c-Cbl, and show similar tissue specific expression [14, 15, 44-48]. Interestingly, a compensatory increase of CAP/ponsin was observed in certain tissues of vinexin (-/-) mice (Kioka, unpublished). Thus, it is likely that vinexin is dispensable under physiological conditions, presumably by functional redundancy with $\mathrm{CAP} /$ ponsin or ArgBP2, but indispensable under pathological conditions including cutaneous wound healing.

In conclusion, we have shown that vinexin plays a crucial role in migration of primary and immortalized keratinocytes in vitro and cutaneous wound healing in vivo. These findings may imply novel therapeutic targets for wound-healing-related diseases 
in skin and other tissues. 


\section{Acknowledgements}

We thank Dr. K. Kadomatsu (Nagoya University) and Dr. M Hara-Chikuma (Kyoto

University) for providing valuable material and technical advice. This work was supported in part by The Naito Foundation and a Grant-in-Aid for Scientific Research

from the Ministry of Education, Culture, Sports, Science, and Technology of Japan. 


\section{References}

[1] P. Martin, Wound healing--aiming for perfect skin regeneration, Science 276 (1997) $75-81$.

[2] A.J. Singer, R.A. Clark, Cutaneous wound healing, N Engl J Med 341 (1999) 738-746.

[3] S. Werner, R. Grose, Regulation of wound healing by growth factors and cytokines, Physiol Rev 83 (2003) 835-870.

[4] G. Fitsialos, A.A. Chassot, L. Turchi, M.A. Dayem, K. LeBrigand, C. Moreilhon, G. Meneguzzi, R. Busca, B. Mari, P. Barbry, G. Ponzio, Transcriptional signature of epidermal keratinocytes subjected to in vitro scratch wounding reveals selective roles for ERK1/2, p38, and phosphatidylinositol 3-kinase signaling pathways, J Biol Chem 282 (2007) 15090-15102.

[5] L.G. Hudson, L.J. McCawley, Contributions of the epidermal growth factor receptor to keratinocyte motility, Microsc Res Tech 43 (1998) 444-455.

[6] L. Koivisto, G. Jiang, L. Hakkinen, B. Chan, H. Larjava, HaCaT keratinocyte migration is dependent on epidermal growth factor receptor signaling and glycogen synthase kinase-3alpha, Exp Cell Res 312 (2006) 2791-2805.

[7] Y. Matsubayashi, M. Ebisuya, S. Honjoh, E. Nishida, ERK activation propagates in epithelial cell sheets and regulates their migration during wound healing, Curr Biol 14 (2004) 731-735.

[8] L. Turchi, A.A. Chassot, R. Rezzonico, K. Yeow, A. Loubat, B. Ferrua, G. Lenegrate, J.P. Ortonne, G. Ponzio, Dynamic characterization of the molecular events during in vitro epidermal wound healing, J Invest Dermatol 119 (2002) 56-63.

[9] A. Scheid, M. Meuli, M. Gassmann, R.H. Wenger, Genetically modified mouse models in studies on cutaneous wound healing, Exp Physiol 85 (2000) 687-704.

[10] A.F. Muro, A.K. Chauhan, S. Gajovic, A. Iaconcig, F. Porro, G. Stanta, F.E. Baralle, Regulated splicing of the fibronectin EDA exon is essential for proper skin wound healing and normal lifespan, J Cell Biol 162 (2003) 149-160.

[11] M.M. Santoro, G. Gaudino, Cellular and molecular facets of keratinocyte reepithelization during wound healing, Exp Cell Res 304 (2005) 274-286.

[12] R. Grose, C. Hutter, W. Bloch, I. Thorey, F.M. Watt, R. Fassler, C. Brakebusch, S. Werner, A crucial role of beta 1 integrins for keratinocyte migration in vitro and 
during cutaneous wound repair, Development 129 (2002) 2303-2315.

[13] S.N. Nikolopoulos, P. Blaikie, T. Yoshioka, W. Guo, C. Puri, C. Tacchetti, F.G. Giancotti, Targeted deletion of the integrin beta4 signaling domain suppresses laminin-5-dependent nuclear entry of mitogen-activated protein kinases and NF-kappaB, causing defects in epidermal growth and migration, Mol Cell Biol 25 (2005) 6090-6102.

[14] N. Kioka, S. Sakata, T. Kawauchi, T. Amachi, S.K. Akiyama, K. Okazaki, C. Yaen, K.M. Yamada, S. Aota, Vinexin: a novel vinculin-binding protein with multiple SH3 domains enhances actin cytoskeletal organization, J Cell Biol 144 (1999) 59-69.

[15] N. Kioka, K. Ueda, T. Amachi, Vinexin, CAP/ponsin, ArgBP2: a Novel Adaptor Protein Family Regulating Cytoskeletal Organization and Signal Transduction, Cell Struct Funct 27 (2002) 1-7.

[16] M. Matsuyama, H. Mizusaki, A. Shimono, T. Mukai, K. Okumura, K. Abe, K. Shimada, K. Morohashi, A novel isoform of Vinexin, Vinexin gamma, regulates Sox9 gene expression through activation of MAPK cascade in mouse fetal gonad, Genes Cells 10 (2005) 421-434.

[17] M. Paz, P.P. Lopez-Casas, J. Del Mazo, Changes in Vinexin Expression Patterns in the Mouse Testis Induced by Developmental Exposure to 17Beta-Estradiol, Biol Reprod (2007).

[18] T. Kawauchi, M. Ikeya, S. Takada, K. Ueda, M. Shirai, Y. Takihara, N. Kioka, T. Amachi, Expression of vinexin alpha in the dorsal half of the eye and in the cardiac outflow tract and atrioventricular canal, Mech Dev 106 (2001) 147-150.

[19] M. Mitsushima, T. Sezaki, R. Akahane, K. Ueda, S. Suetsugu, T. Takenawa, N. Kioka, Protein kinase A-dependent increase in WAVE2 expression induced by the focal adhesion protein vinexin, Genes Cells 11 (2006) 281-292.

[20] M. Mitsushima, H. Takahashi, T. Shishido, K. Ueda, N. Kioka, Abl kinase interacts with and phosphorylates vinexin, FEBS Lett 580 (2006) 4288-4295.

[21] M. Wakabayashi, T. Ito, M. Mitsushima, S. Aizawa, K. Ueda, T. Amachi, N. Kioka, Interaction of lp-dlg/KIAA0583, a membrane-associated guanylate kinase family protein, with vinexin and beta-catenin at sites of cell-cell contact, J Biol Chem 278 (2003) 21709-21714.

[22] A. Kimura, C.A. Baumann, S.H. Chiang, A.R. Saltiel, The sorbin homology domain: a motif for the targeting of proteins to lipid rafts, Proc Natl Acad Sci U S A 98 (2001) 
9098-9103.

[23] M. Tujague, J.S. Thomsen, K. Mizuki, C.M. Sadek, J.A. Gustafsson, The focal adhesion protein vinexin alpha regulates the phosphorylation and activity of estrogen receptor alpha, J Biol Chem 279 (2004) 9255-9263.

[24] H. Takahashi, M. Mitsushima, N. Okada, T. Ito, S. Aizawa, R. Akahane, T. Umemoto, K. Ueda, N. Kioka, Role of interaction with vinculin in recruitment of vinexins to focal adhesions, Biochem Biophys Res Commun 336 (2005) 239-246.

[25] M. Mitsushima, A. Suwa, T. Amachi, K. Ueda, N. Kioka, Extracellular signal-regulated kinase activated by epidermal growth factor and cell adhesion interacts with and phosphorylates vinexin, J Biol Chem 279 (2004) 34570-34577.

[26] M. Mitsushima, K. Ueda, N. Kioka, Involvement of phosphatases in the anchorage-dependent regulation of ERK2 activation, Exp Cell Res 313 (2007) 1830-1838

[27] M. Mitsushima, K. Ueda, N. Kioka, Vinexin beta regulates the phosphorylation of epidermal growth factor receptor on the cell surface, Genes Cells 11 (2006) 971-982.

[28] M. Hara-Chikuma, A.S. Verkman, Aquaporin-3 facilitates epidermal cell migration and proliferation during wound healing, J Mol Med 86 (2008) 221-231.

[29] K. Takahashi, B. Yan, K. Yamanishi, S. Imamura, P.A. Coulombe, The two functional keratin 6 genes of mouse are differentially regulated and evolved independently from their human orthologs, Genomics 53 (1998) 170-183.

[30] H. Chen, D.M. Cohen, B. Choudhury, N. Kioka, E.D. Adamson, S.W. Craig, Spatial Distribution and Functional Significance of Activated Vinculin in Living Cells, J Cell Biol 169 (2005) 459-470.

[31] T. Igakura, K. Kadomatsu, T. Kaname, H. Muramatsu, Q.W. Fan, T. Miyauchi, Y. Toyama, N. Kuno, S. Yuasa, M. Takahashi, T. Senda, O. Taguchi, K. Yamamura, K. Arimura, T. Muramatsu, A null mutation in basigin, an immunoglobulin superfamily member, indicates its important roles in peri-implantation development and spermatogenesis, Dev Biol 194 (1998) 152-165.

[32] T. Yagi, T. Tokunaga, Y. Furuta, S. Nada, M. Yoshida, T. Tsukada, Y. Saga, N. Takeda, Y. Ikawa, S. Aizawa, A novel ES cell line, TT2, with high germline-differentiating potency, Anal Biochem 214 (1993) 70-76.

[33] V. Falanga, D. Schrayer, J. Cha, J. Butmarc, P. Carson, A.B. Roberts, S.J. Kim, Full-thickness wounding of the mouse tail as a model for delayed wound healing: 
accelerated wound closure in Smad3 knock-out mice, Wound Repair Regen 12 (2004) 320-326.

[34] J.D. Whittard, S.K. Akiyama, Activation of beta1 integrins induces cell-cell adhesion, Exp Cell Res 263 (2001) 65-76.

[35] S.K. Repertinger, E. Campagnaro, J. Fuhrman, T. El-Abaseri, S.H. Yuspa, L.A. Hansen, EGFR enhances early healing after cutaneous incisional wounding, J Invest Dermatol 123 (2004) 982-989.

[36] Y. Shirakata, R. Kimura, D. Nanba, R. Iwamoto, S. Tokumaru, C. Morimoto, K. Yokota, M. Nakamura, K. Sayama, E. Mekada, S. Higashiyama, K. Hashimoto, Heparin-binding EGF-like growth factor accelerates keratinocyte migration and skin wound healing, J Cell Sci 118 (2005) 2363-2370.

[37] A. Suwa, M. Mitsushima, T. Ito, M. Akamatsu, K. Ueda, T. Amachi, N. Kioka, Vinexin beta Regulates the Anchorage Dependence of ERK2 Activation Stimulated by Epidermal Growth Factor, J Biol Chem 277 (2002) 13053-13058.

[38] C.B. Thien, W.Y. Langdon, Cbl: many adaptations to regulate protein tyrosine kinases, Nat Rev Mol Cell Biol 2 (2001) 294-307.

[39] K. Mizutani, H. Ito, I. Iwamoto, R. Morishita, T. Deguchi, Y. Nozawa, T. Asano, K.I. Nagata, Essential roles of ERK-mediated phosphorylation of vinexin in cell spreading, migration and anchorage-independent growth, Oncogene (2007).

[40] T. Umemoto, T. Inomoto, K. Ueda, M. Hamaguchi, N. Kioka, v-Src-mediated Transformation Suppresses the Expression of Focal Adhesion Protein Vinexin, Cancer Lett in press (2009).

[41] I. Chandrasekar, T.E. Stradal, M.R. Holt, F. Entschladen, B.M. Jockusch, W.H. Ziegler, Vinculin acts as a sensor in lipid regulation of adhesion-site turnover, J Cell Sci 118 (2005) 1461-1472.

[42] R.M. Saunders, M.R. Holt, L. Jennings, D.H. Sutton, I.L. Barsukov, A. Bobkov, R.C. Liddington, E.A. Adamson, G.A. Dunn, D.R. Critchley, Role of vinculin in regulating focal adhesion turnover, Eur J Cell Biol 85 (2006) 487-500.

[43] T. Takenawa, S. Suetsugu, The WASP-WAVE protein network: connecting the membrane to the cytoskeleton, Nat Rev Mol Cell Biol 8 (2007) 37-48.

[44] M. Zhang, J. Liu, A. Cheng, S.M. Deyoung, X. Chen, L.H. Dold, A.R. Saltiel, CAP interacts with cytoskeletal proteins and regulates adhesion-mediated ERK activation and motility, Embo J 25 (2006) 5284-5293. 
[45] I. Vandenbroere, N. Paternotte, J.E. Dumont, C. Erneux, I. Pirson, The c-Cbl-associated protein and c-Cbl are two new partners of the SH2-containing inositol polyphosphate 5-phosphatase SHIP2, Biochem Biophys Res Commun 300 (2003) 494-500.

[46] V. Ribon, J.A. Printen, N.G. Hoffman, B.K. Kay, A.R. Saltiel, A novel, multifuntional c-Cbl binding protein in insulin receptor signaling in 3T3-L1 adipocytes, Mol Cell Biol 18 (1998) 872-879.

[47] B. Wang, E.A. Golemis, G.D. Kruh, ArgBP2, a multiple Src homology 3 domain-containing, Arg/Abl- interacting protein, is phosphorylated in $\mathrm{v}$-Abl-transformed cells and localized in stress fibers and cardiocyte Z-disks, J Biol Chem 272 (1997) 17542-17550.

[48] K. Mandai, H. Nakanishi, A. Satoh, K. Takahashi, K. Satoh, H. Nishioka, A. Mizoguchi, Y. Takai, Ponsin/SH3P12: An l-Afadin- and Vinculin-binding Protein Localized at Cell-Cell and Cell-Matrix Adherens Junctions, J Cell Biol 144 (1999) 1001-1018. 


\section{Figure legends}

Fig. 1. Scratch assay of HaCaT keratinocytes and A431 epidermoid carcinoma cells. HaCaT keratinocytes (A, B, C) or A431 epidermoid carcinoma cells (D, E, F) were transfected with control siRNA or vinexin siRNA1. A, D. Knockdown of vinexin expression was confirmed by immunoblotting with anti-vinexin antibody. B, E. Cells were cultured to confluence, then photographed immediately $(0 \mathrm{hr})$, or at the indicated hours after scratching. C, F. Quantification of cell migration during 24 hours or 18 hours after scratching. Error bars represent standard error $(n=6)$.

\section{Fig. 2. Effect of EGFR and ERK inhibition on defect closure of HaCaT and A431} monolayer cells. A, D. HaCaT (A) or A431 (D) cells were cultured to confluence and wounded mechanically by scratching. Cells were then lysed 2, 4, or 8 hours after wounding. Lysates were immunoblotted with the indicated antibodies. B, C, E, F. HaCaT $(\mathrm{B}, \mathrm{C})$ or A431 (E, F) cells were cultured to confluence and wounded by scratching. Cells were then incubated with medium containing AG1478 or U0126 for the indicated hours and photographed. C, E. Quantification of cell migration during 20 hours after scratching. Error bars represent standard error $(\mathrm{n}=6)$. Asterisks denote $\mathrm{P}<$ 0.01 .

Fig. 3. Effect of vinexin knockdown on EGFR and ERK activation. HaCaT cells (A, B) or A431 cells (D) were transfected with control siRNA or vinexin siRNA1. Cells were then cultured to confluence and lysed 4 or 8 hours after scratching. Lysates were immunoblotted with the indicated antibodies. C, F. Quantification of phosphorylated EGFR. Values are expressed as a ratio to the phosphorylated EGFR normalized by vinculin (C) or EGFR (F) in control cells at 0 hrs. Asterisks denote $\mathrm{P}<0.05$.

Fig. 4. Subcellular localization of EGFR and vinculin in migrating A431 cells. A431 cells were transfected with control siRNA or vinexin siRNA1 and cultured to confluence for three days. Cell monolayer was then scratched and incubated for an additional five hours. Cells were fixed and immunostained using the indicated antibodies. Merged images were shown at the right. Arrows indicate the localization of 
vinculin (A) at focal contacts of the leading edge and arrowheads indicate the colocalization of EGFR and vinexin (B) at the leading edge. White lines show the edge of the migrating cells. Note that localization of EGFR at cell-cell adhesion sites were not affected by vinexin knockdown. Scale bar indicates $10 \mu \mathrm{m}$.

\section{Fig. 5. Scratch assay of primary keratinocytes isolated from wild-type and vinexin} (-/-) mice. Primary keratinocytes were isolated from wild-type or vinexin (-/-) cells. A.

Cell lysates extracted from primary keratinocytes were immunoblotted with anti-vinexin or anti-vinculin antibody. B. The cell-attachment activities of primary keratinocytes were assayed by a cell attachment assay using collagen I-coated plates. The percentages of cells that attached onto collagen were determined. C. Primary keratinocytes were seeded into Transwell chambers coated with collagen I. After incubation for 6 hours, cells on the bottom surface of the membrane were counted. D. Primary keratinocytes were cultured to confluence. Cell migration during 22 hours after scratching was determined. Asterisks denote $\mathrm{P}<0.01$. Error bars mean standard error.

Fig. 6. Wound closure of wild-type and vinexin (-/-) mice in vivo. A. Wound healing of the back skin of vinexin (-/-) mice. Two full-thickness wounds were created on the skin of the backs of wild-type or vinexin (-/-) mice using an 8-mm biopsy punch. Each wound was photographed with a ruler, and the wounded area quantitated by ImageJ is shown as a percentage. Error bars represent standard error $(n=8 \sim 10)$. Results representative of two independent experiments are shown. B. Wound healing on the tail skin of vinexin (-/-) mice. Full-thickness wounds were created using a scalpel on the dorsal aspect of the tail of wild-type and vinexin (-/-) mice. Micrographs of H-E stained section of tails harvested at day 8 after wounding. Bar, $1 \mathrm{~mm}$. Black arrows indicate re-epithelialized region. C. Re-epithelialized length in wounding on tail skin of wild-type and vinexin (-/-) mice at day 4 or 8 after wounding. Error bars represent standard error $(n=6 \sim 10)$. Results representative of two independent experiments are shown. D. Cell number of Ki-67 positive keratinocytes per $500 \mu \mathrm{m}$ of wounded area on tail skin of wild-type and vinexin (-/-) mice. Error bars represent standard error $(n=8-10)$. 
A

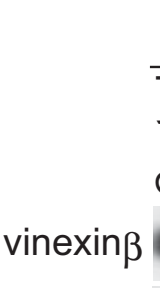

vinculin

ERK2

D

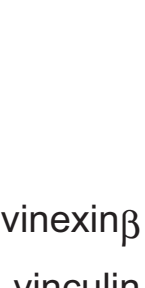

vinculin

ERK2
B

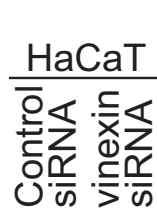

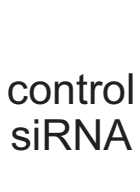

vinexin siRNA1
$\mathrm{HaCaT}$

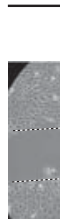

\section{$0 \mathrm{hr}$}

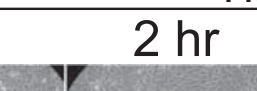

.
$8 \mathrm{hr}$

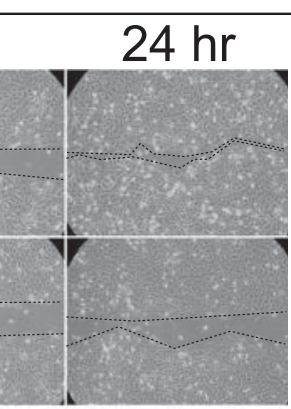

E

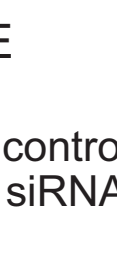

vinexin siRNA1

A431
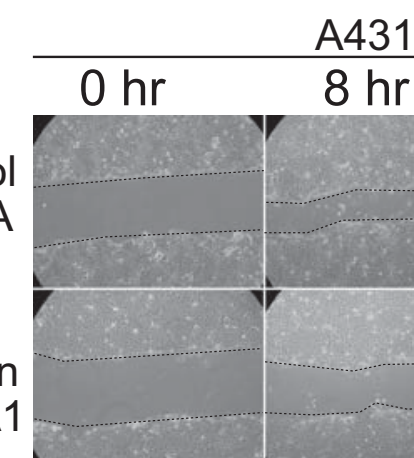

C

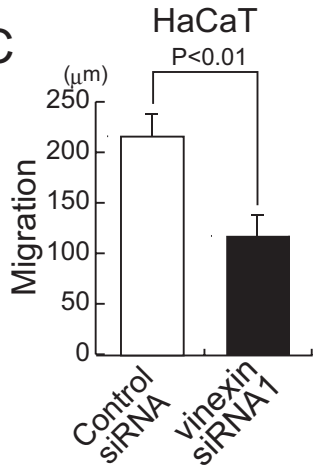

$\mathrm{F}$

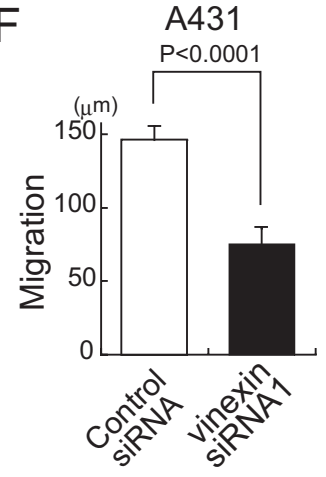

Fig. 1 Kioka et al. 
A

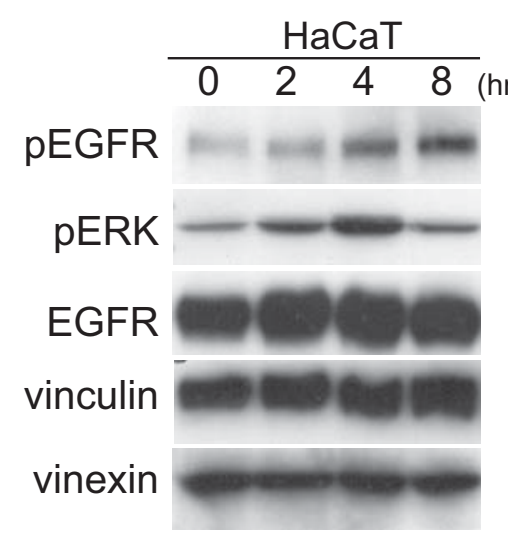

D

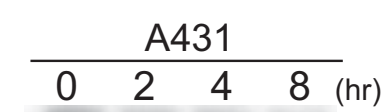

pEGFR

pERK

\section{EGFR}

vinculin

vinexin
B

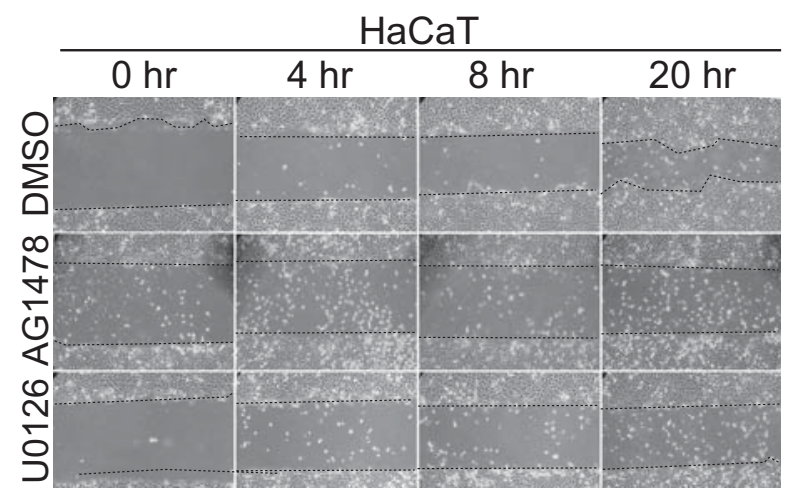

E

E

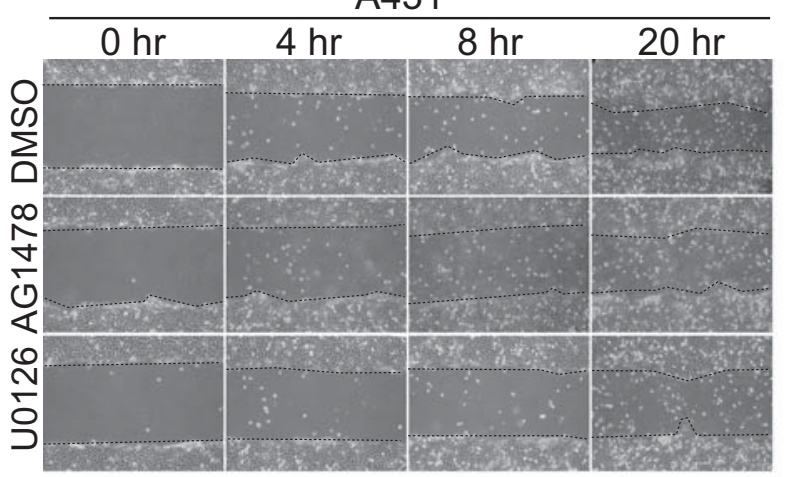

C
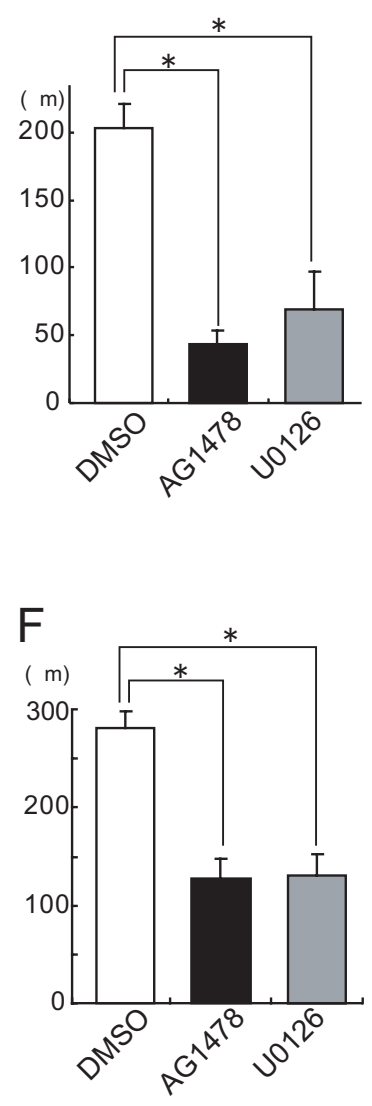

Fig. 2 Kioka et al. 
A

$\underset{(1068)}{p E G F R}$

$\frac{\text { Control }}{044 \quad 8} \frac{\substack{\text { vinexin } \\ \text { siRNA }}}{044 \quad 8(\mathrm{hr})}$

EGFR

pERK

ERK

vinexin

\section{pEGFR \\ (845)}

pEGFR

(992)

\section{pEGFR}

(1173)

vinculin

C
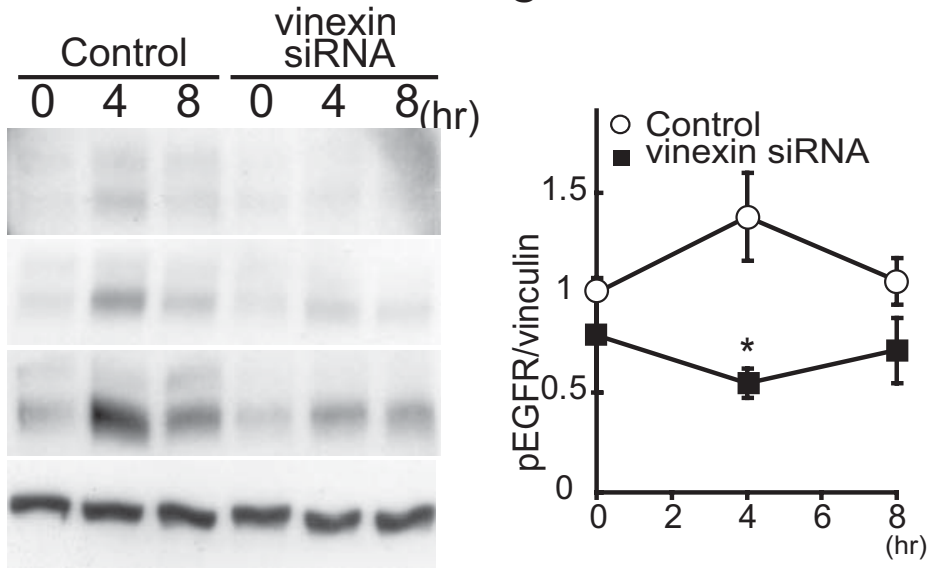

D

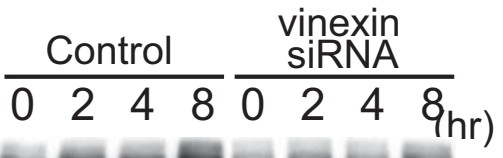

pEGFR

EGFR

pERK

ERK

vinexin
E

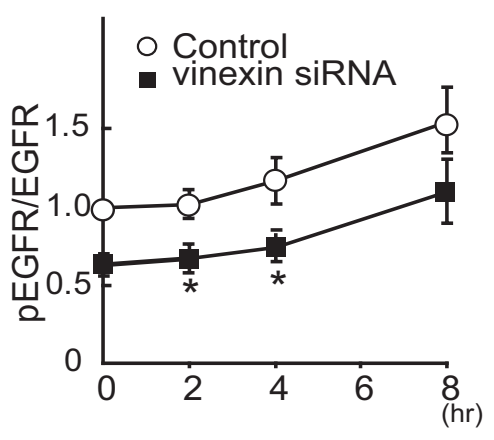

Fig. 3 Kioka et al. 


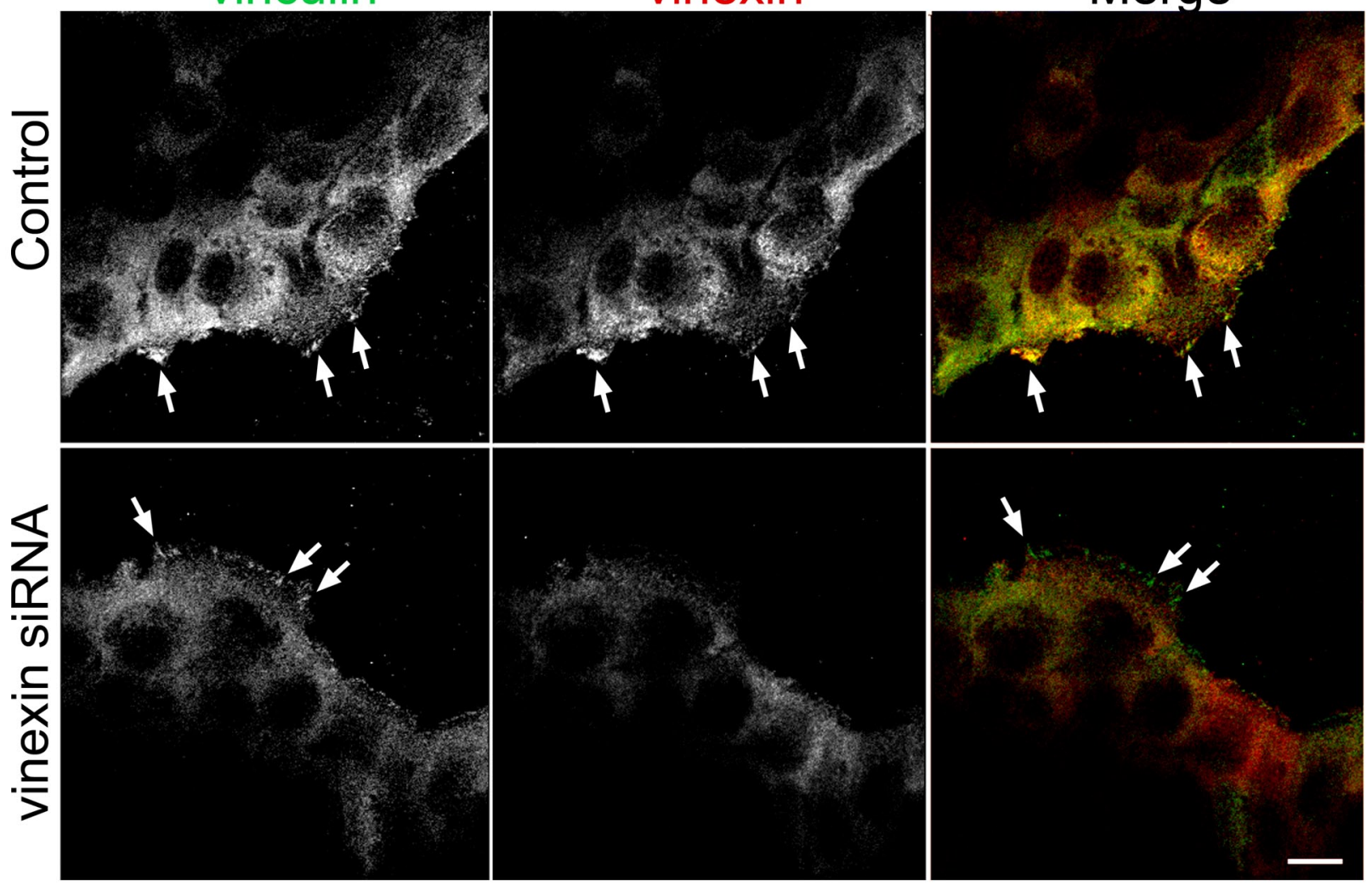

B

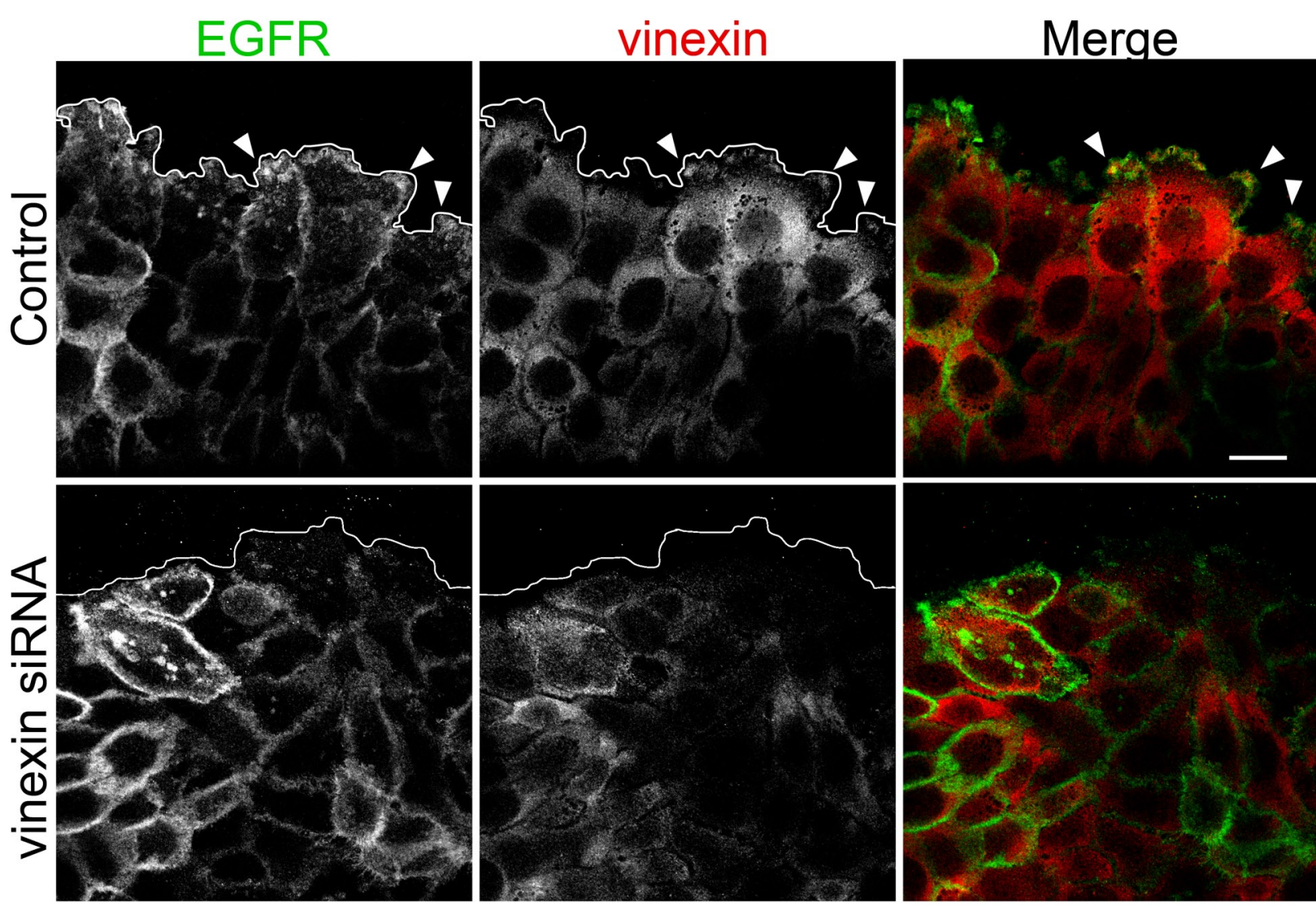


A

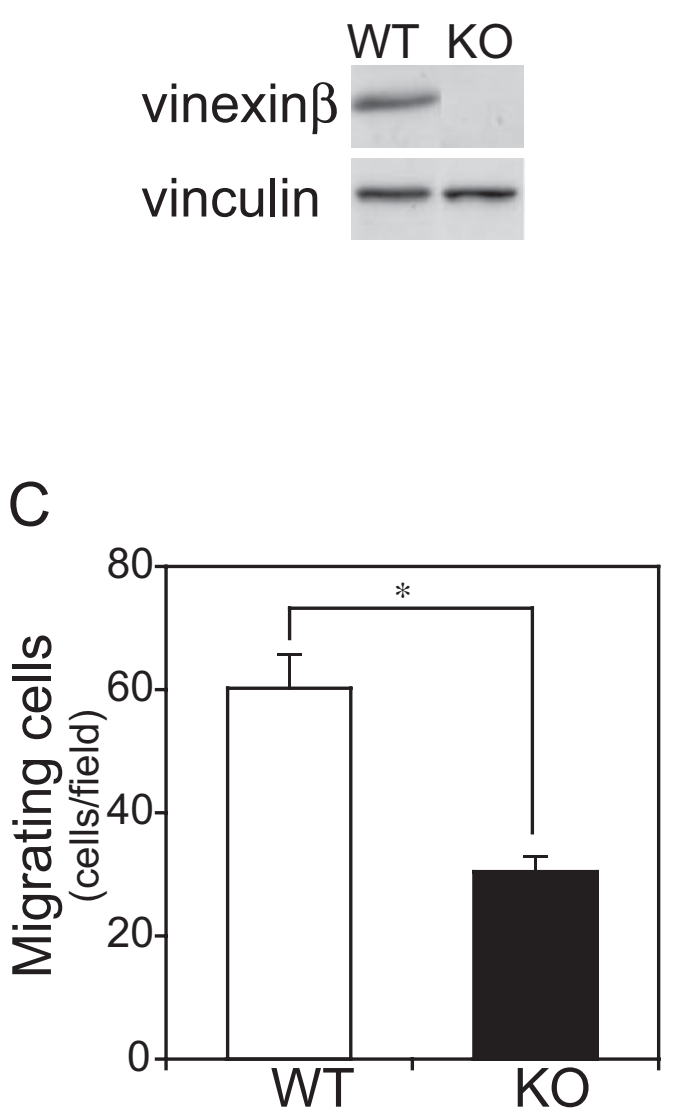

B
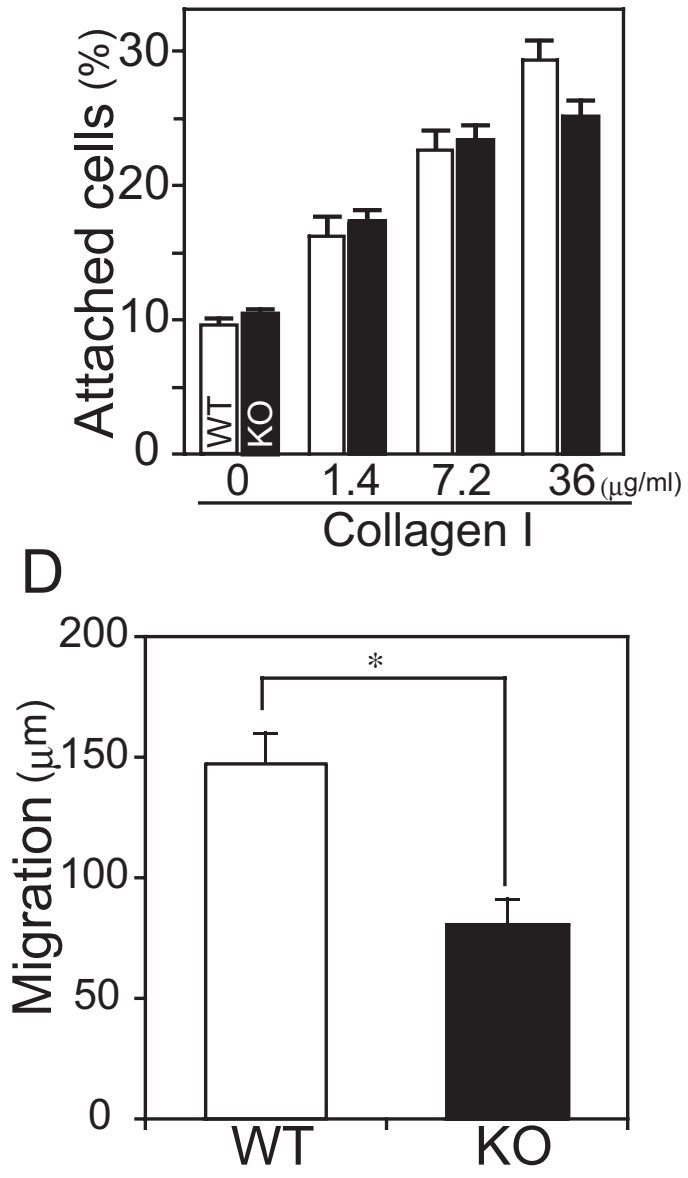

Fig. 5 Kioka et al. 
A

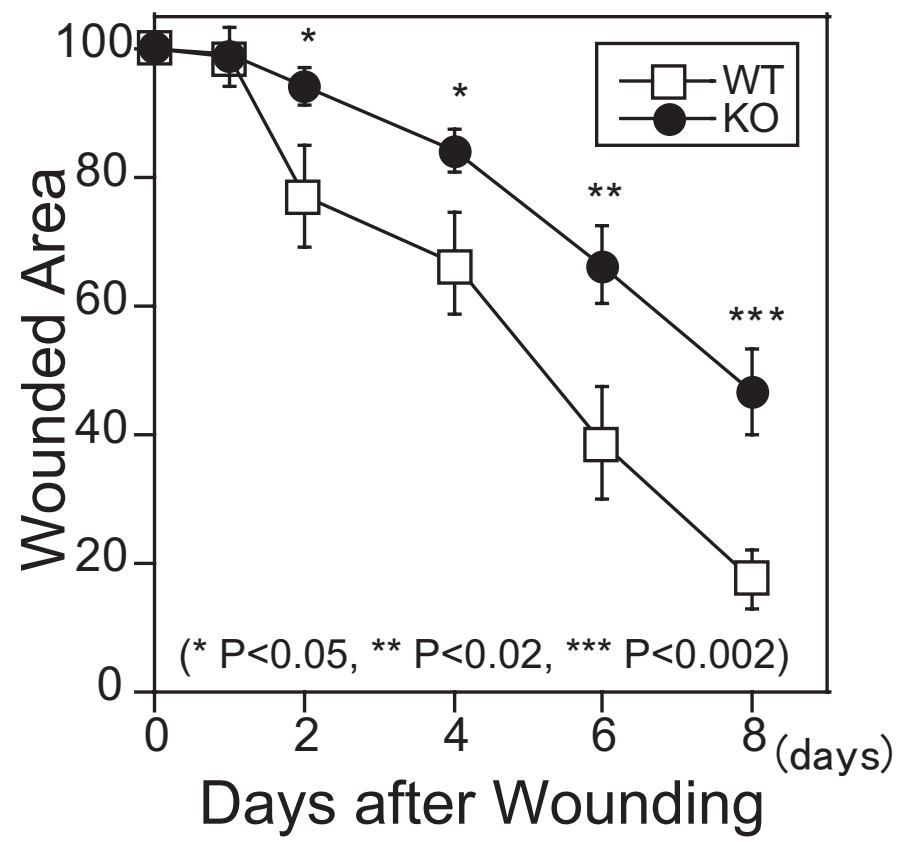

C

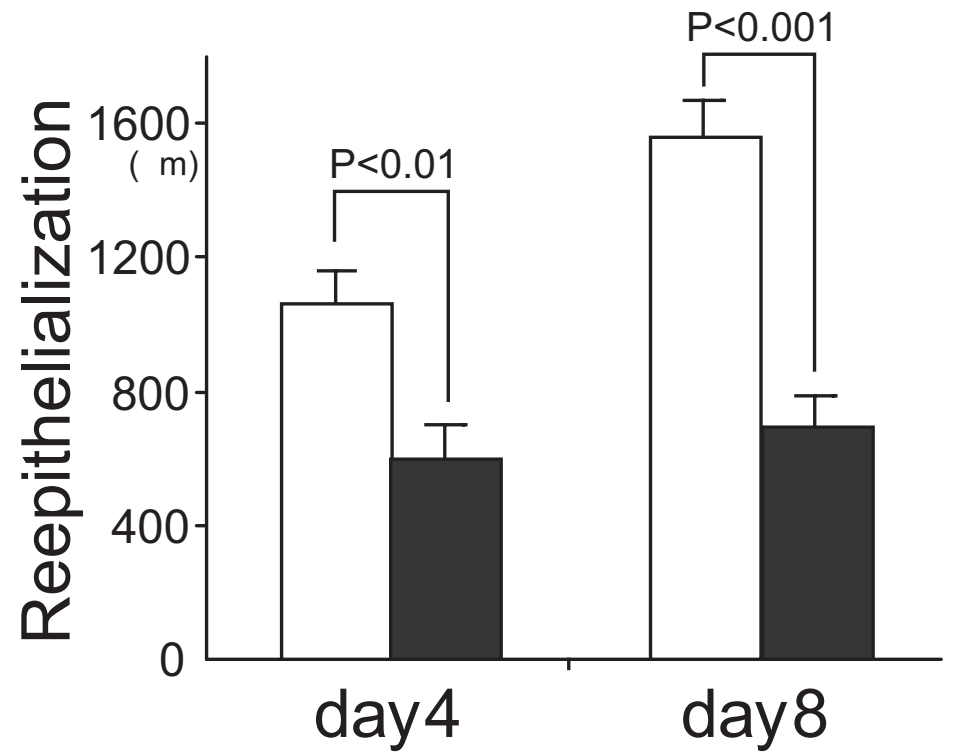

B

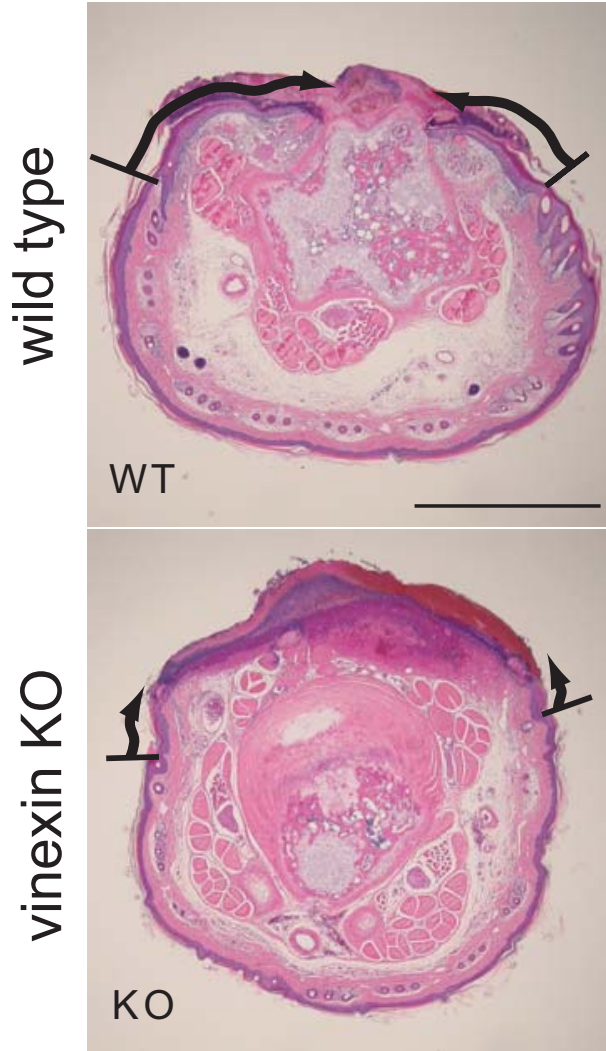

D

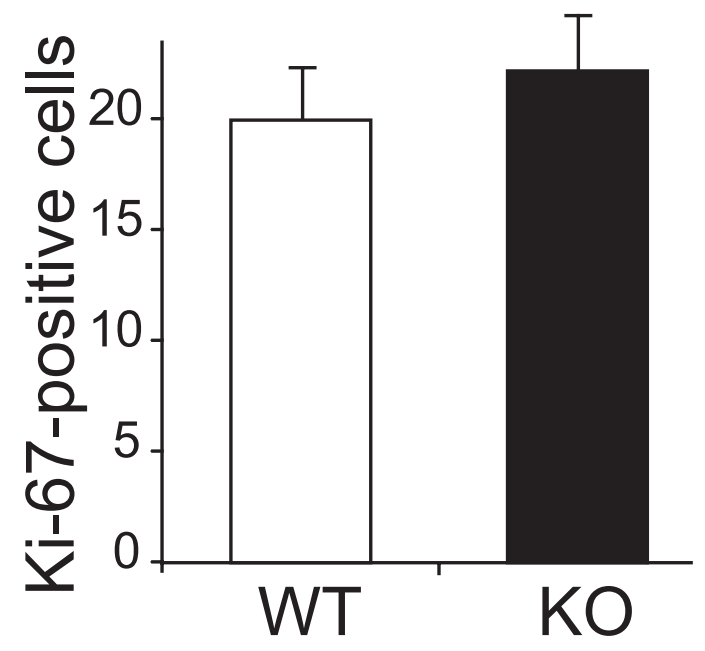

Fig. 6 Kioka et al. 